\title{
A QUESTÃO DA EFETIVIDADE DO PROCESSO PENAL AMBIENTAL: DELINEANDO UM ELEMENTO OTIMIZADOR
}

Jônica Marques Coura Aragão

Doutora em Ciências Jurídicas e Sociais, Universidad del Museo Social Argentino (UMSA), Buenos Aires-Argentina. Mestre em Desenvolvimento e Meio Ambiente, Universidade Federal da Paraíba (UFPB), Paraíba-Brasil. Aluna do Doutorado em Recursos Naturais, Universidade Federal de Campina Grande (UFCG), Paraíba -Brasil. Professora Adjunto I do Curso de Direito da Universidade Federal de Campina Grande (UFCG) e-mail: jonicamca@ufcg.edu.br/jonicamca@gmail.com

\section{Resumo}

A questão ambiental traduz-se como um problema transnacional que acompanha a história da humanidade e, a despeito da visível evolução científica e tecnológica, demonstra-se sempre mais agravada. Não obstante pretendam os postulados desenvolvimentistas interpretar o meio ambiente como fonte de admirável resiliência, observa-se que resta provada a fragilidade existencial da biosfera, cabendo à humanidade o dever de preservar o ambiente para a atual e as futuras geraçôes. Diante dessa responsabilidade, a Justiça é a instituição designada para fazer cumprir o que a norma ambiental (nacional ou supranacional) define como conduta obrigatória, devendo conferir especial atenção às previsōes de crime, vez que são essas as condutas mais gravosas ao objeto jurídico protegido, contudo, esta não é uma atividade simples. $\mathrm{O}$ direito penal ambiental é polêmico, enfrenta variáveis delicadas, assim como o processo penal ambiental, pois se trata de processo penal incomum; consiste em espécie do gênero processo penal difuso/coletivo, por isso, tem-se como objetivo geral analisar a possibilidade jurídica de inserção de um elemento otimizador no bojo do processo penal ambiental, capaz de lhe conferir a efetividade almejada. Assim, esta pesquisa é de natureza explicativa e, para tanto, emprega os métodos sistêmico e hipotético-dedutivo. Observa-se a utilizaçâo da técnica de pesquisa bibliográfica para realizar uma abordagem jurídica do recorte espaço-temporal do objeto da pesquisa, ou seja, o sistema penal ambiental brasileiro sob o pálio da Constituição Federal de 1998. Por essa perspectiva, observa-se que para equacionar a questáo penal ambiental, para além da perspectiva jurídico-legal, subsiste a necessidade da participação da cidadania ética no bojo do processo, como via legítima para se implementar justiça penal, ambiental e social; tal propósito é bastante para alterar a própria representação da relação processual, formal e materialmente, e tem como pressuposto lógico os postulados do Estado Democrático de Direito. 


\section{Palavras-chave}

Crime ambiental; Proteção jurídica ao ambiente; Responsabilidade cidadã.

\section{Resumen}

La cuestión ambiental traduce como un problema transnacional que acompaña la historia de la humanidad demostrándose, a despecho de la visible evolución científica y tecnológica, siempre más agravada. No obstante pretendan los postulados progresistas interpretar el medio ambiente como fuente de admirable capacidad de recuperación, observase que resta probada la fragilidad existencial de la biosfera, cabiendo a la humanidad el deber de preservar el ambiente para la actual y las futuras generaciones. Delante de esa responsabilidad, la Justicia es la institución designada para hacer cumplir lo que la norma ambiental (nacional o supranacional) define como conducta obligatoria; debiendo conferir especial atención a las previsiones de crimen, a la vez que son esas las conductas más agravantes al objeto jurídico protegido. Con todo, esta no es una actividad simple; el derecho penal ambiental es polémico, enfrenta variables delicadas; así como el proceso penal ambiental. Se trata de proceso penal poco común. Consiste en una especie del género proceso penal difuso/colectivo. Se muestra el objetivo general: analizar la posibilidad jurídica de la inserción de un elemento optimizador para que haya efectividad en ese sistema procesal penal. Así la investigación que se desenvuelve es de naturaleza explicativa, con la pretensión de identificar la existencia de relaciones entre las variables pertinentes al tema investigado y, además de eso, determinar la naturaleza de esa relación; para tanto emplea los métodos: sistémico y también lo hipotético-deductivo. Se observa la utilización de la técnica de investigación bibliográfica para realizar un abordaje jurídico del recorte espacio-temporal del objeto de la investigación, cual sea, el sistema penal ambiental brasileńo planteado em la Constituición Federal de 1998. Por esa perspectiva se observa que para solucionar la cuestión penal/ambiental, para allá de la perspectiva jurídico-legal, subsiste la necesidad de la participación de la ciudadanía ética en el ápice del proceso, como vía legítima para implementarse justicia penal, ambiental y social; tal propósito es bastante para alterar a propia representación de la relación procesal, formal y materialmente tiendo como presupuesto lógico la base común representada por todo Estado Democrático de Derecho.

\section{Palabras clave}

Crimen ambiental; Protección jurídica al ambiente; Responsabilidad ciudadana.

\section{Introdução}

O ser humano como ser racional que sabe e tem consciência desse saber, é totalmente responsável por sua conduta, quase sempre destrutiva e inconsequente, no que diz 
respeito às questóes ambientais. $\mathrm{Na}$ atual cultura predatória, o homem pratica, sem maiores preocupaçôes, atos de destruição contra o meio ambiente, incidindo, assim, em condutas gravosas não raro qualificadas como crime nos respectivos ordenamentos jurídicos.

Observa-se que tanto maior e mais grave a ofensa penal ambiental maior se revela a burocracia e o tecnicismo do sistema jurídico-processual, que, quase sempre, em razáo desses aspectos, acaba por beneficiar o infrator em detrimento do objeto jurídico a ser protegido, qual seja o meio ambiente.

A visão antropocêntrica e o despreparo técnico e científico dos juristas ao tratar das questóes ambientais, a insuficiência de conhecimento ambiental específico e a ausência permissiva por parte do cidadão ao investigar e punir crimes ambientais são constataçôes que implicam em grave lacuna no estado de conhecimento atual da área-problema, justificando, assim, a motivação à escolha do relevante tema, tanto à academia como à sociedade e ao Estado.

Por essa razão, a pesquisa a ser realizada se propóe a investigar o sistema processual penal ambiental em seu aspecto qualitativo, sobretudo quanto à participação direta do cidadão na dinâmica processual desse sistema, pretendendo, ao final, responder à seguinte problematização: Estaria o sistema processual penal ambiental, tal como se apresenta, atingindo sua finalidade de proteção ao meio ambiente? Como hipótese, apontar-se-á que não; face à ausência de comprometimento ou conhecimento específico por parte dos sujeitos processuais envolvidos.

Desse modo, apontar-se-á como objetivo geral da pesquisa, analisar a possibilidade jurídica da participação direta do cidadão no bojo da relação processual, como instrumento otimizador da efetividade do processo penal ambiental.

Como objetivo específico o propósito de investigar a importância da proteção penal ambiental em tempos de sociedade do risco e de modernidade reflexiva, com suporte teórico nos postulados do minimalismo e do garantismo penal.

Também consistirá objetivo específico a ideia de estratificar a dinâmica do direito processual penal clássico, verificando a eficiência desse sistema, no que diz respeito à proteção do bem jurídico protegido pela legislação penal ambiental, submetendo-o ao contraponto da presença de um traço especializante, com embasamento na interpretação aberta, plural e democrática do sistema penal ambiental, para verificar a viabilidade jurídica de um processo penal ambiental mais efetivo.

Propóe-se, assim, o desenvolvimento de uma pesquisa explicativa, com a pretensão de identificar a existência de relaçóes entre as variáveis correlatas ao tema investigado e determinar a natureza dessa relação. Para tanto, serão empregados os métodos sistêmico e hipotético-dedutivo. 
Somente sob uma perspectiva sistêmica o objeto da pesquisa poderá ser estudado, face ao conjunto de elementos em que se constitui o sistema jurídico, cuja análise se deterá na dinâmica que o sustenta, sob o enfoque, inicial, de um sistema fechado, autopoiético.

Acrescentar-se-á nesse ponto, como viés de interação e ponto de abertura do sistema, o postulado de um agir comunicativo, estabelecido entre o sistema jurídico- penal e o sistema social, pelos sujeitos que os compóem, ao estabelecerem um diálogo democrático em busca da efetividade de ambos os sistemas.

Para tanto, será empregado o método hipotético-dedutivo a partir da adoção da hipótese extraída do contexto teórico para inserção do elemento inovador no bojo do processo penal ambiental, objeto da pesquisa, a título de conjectura formulada, por consistir em hipótese à problematização que a pesquisa se propóe a investigar.

Compreende-se, contudo, que necessário se fará a submissão da conjectura a um rigoroso processo de falseamento. Tal proceder será contínuo em todo o desenvolvimento da pesquisa e, ainda assim, sabe-se que não restará exaurido ao final do trabalho, pois esse método subsiste do processo de teorias e refutaçôes - em processo evolutivo constante.

Para desenvolver a pesquisa será utilizada a técnica bibliográfica, objetivando realizar uma abordagem jurídico-legal e social acerca do recorte espaço-temporal onde está inserido o problema da pesquisa, ou seja, o sistema penal ambiental em Estados Democráticos como o Brasil, em tempos de sociedade do risco. Tal procedimento se verificará de modo a que se realize uma análise sistêmica a partir de uma conjectura apresentada como elemento de inovação no processo penal ambiental.

Por essa perspectiva, observa-se que, para equacionar a questáo penal ambiental, para além da perspectiva jurídico-legal, subsiste a necessidade da participação direta do cidadão no bojo do processo, como via legítima para se implementar justiça penal, ambiental e social sob o influxo de moderado funcionalismo teleológico. Por fim, acrescente-se que será demonstrado que esse constructo teórico norteia o novo padrão de democracia, não mais centrada na figura do Estado; antes visando chamar ao centro os cidadãos; para que participem ativamente dos processos penais ambientais, como autêntico elemento legitimante do Estado Democrático de Direito.

\section{0 Sistema Penal Ambiental e as suas Especificidades}

Pretendendo construir "um raciocínio amparado em revisão bibliográfica rigorosa", consoante orientam Mezzaroba e Monteiro (2005), compreendeu-se necessário começar a análise da problemática proposta para a pesquisa, fazendo a investigação a partir do sistema penal ambiental com as suas especificidades, considerando que é precisamente nesse ponto, que os encaminhmentos para solução do problema, tal como se apresenta hodiernamente, se demonstram equivocados. 
Em tempos de pós-modernidade a sociedade apesenta-se totalmente envolvida no cenário de alteraçóes paradigmáticas; reflexiva tanto no cenário natural, quanto no cenário social dos interesses humanos; desde os mais rotineiros, aos mais improváveis. $\mathrm{O}$ processo de crise no mundo hodierno é patente, bem assim, as muitas consequências advindas deste cenário. Diante de tantas mudanças, o Direito Penal também se altera substancialmente, seguindo a urgência do momento, municia os seus institutos no destacamento preventivo, mais ainda, antecipando-se à ofensa a ser perpetrada, verdadeiro momento de expansão penal.

Assim ocorre principalmente por força do caráter reflexivo do risco apresentado na conduta ou ante a iminência dela. Para esclarecer, dispóe Bottini (2007, p. 87) nos seguintes termos: "A expansão do direito penal não seria tão voraz e repentina, se caso contrário não existisse o caráter reflexivo dos novos riscos, seria ao contrário lenta e gradual”. Mais adiante, o mesmo autor indica os instrumentos adotados pelo Direito Penal para o enfrentamento do novo e arrebatador contexto fático social:

A complexidade que envolve os novos riscos exige do direito penal maior agilidade para a identificação de perigos potenciais, e esta agilidade estará vinculada ao desenvolvimento de regras complementares aos tipos básicos, produzidas por outras esferas de regulamentação. A utilização das normas penais em branco não é novidade no ordenamento jurídico penal, mas a frequência e a forma com que esta técnica é empregada deve ser objeto de atenção, especialmente no que concerne à observância de princípios basilares do direito penal de um Estado Democrático de Direito.

\section{$[\ldots]$}

A criminalização de condutas por meio desta técnica (delito de perigo abstrato) visa a antecipaçáo da incidência da norma, para afetar condutas antes da verificação de qualquer resultado lesivo. (BOTTINI, 2007, p. 94-95).

Em verdade a alteração verificada no âmbito penal, em franco movimento expansionista, consoante destacado por Roxin (2004), em outras palavras, afigura-se como um mal necessário ao cenário pós-moderno. Corroborando com essa constatação, está o deslocamento do bem jurídico-penal, antes centrado no indivíduo, agora repousando, preferencialmente, segundo o novo catálogo, em bens de caráter difuso, a exemplo do meio ambiente.

Por outro lado, ponderando quanto aos efeitos desse processo de hiper-regulamentação penal, dispõe Wacquant (2001, p.80) que "A atrofia deliberada do Estado social corresponde à hipertrofia distópica do Estado penal: a miséria e a extinção de um tem como contrapartida direta e necessária a grandeza e a prosperidade insolente do outro". 
Observa-se uma grande aclamação na sociedade globalizada pela performance penal na tentativa de solucionar os problemas que, mediante a atuação ou a omissão de outros meios de pacificação social, não foram debelados. Podendo ser notada a incompetência ou, ao menos, a inadequação da política de gestão. Assim, toda a carga de insegurança social termina por enxergar na força coercitiva do Direito Penal o último (senáo o único) caminho em busca da paz.

A legislação penal vai, assim, perdendo a sua característica de exceção do sistema jurídico, ao passo que assume a condição de primeira regra, ampliando significativamente o campo de proteção a bens jurídicos de titularidade coletiva ou difusa, tais como a saúde pública, a paz pública, as finanças públicas, o meio ambiente. Tudo isso, somado ao seu campo originário, torna o Direito Penal uma espécie de super-herói do sistema jurídico.

O fato é que instaurou-se um lamentável ciclo vicioso: o Direito Penal se expande para solucionar todos os problemas sociais - o processo de solução falha - os problemas se avolumam e revoltam a sociedade - o Direito Penal volta a agigantar-se pretendendo sanar as falhas protetivas - o processo falha novamente e o ciclo parece infinito. Sáo muitos os focos de instabilidade e incoerência identificados, apresentado-se diversas posiçóes teóricas acerca do problema.

Diante de tamanho o dissenso teórico, para alguns aspectos mais polêmicos, a doutrina tem proposto a criação de um novo direito que vem sendo denominado de Direito de Intervenção. Nesse sentido, Hassemer (1994, p.49):

Acho que o Direito Penal tem que abrir mão dessas partes modernas que examinei. O Direito Penal deve voltar ao aspecto central, ao Direito Penal formal, a um campo no qual pode funcionar, que são os bens e direitos individuais, vida, liberdade, propriedade, integridade física, enfim, direitos que podem ser descritos com precisão, cuja lesáo pode ser objeto de um processo penal normal. [...] Acredito que é necessário pensarmos em um novo campo do direito que não aplique as pesadas sançóes do Direito Penal, sobretudo as sançóes de privaçáo de liberdade e que, ao mesmo tempo possa ter garantias menores. Eu vou chamá-lo de Direito de Intervenção.

Malgrado a boa intenção quanto à mudança de nome e quanto ao giro teórico proposto por Hassemer (1994), sabe-se que não basta isso para que tudo se resolva. O fato é bem mais complexo. Depreende-se, portanto, de adequaçóes na estrutura funcional desse ramo do direito. Em termos de adequações, alguns entendem necessária uma flexibilização do Direito Penal, ou ainda, a sua setorização, imposta pelo direito penal globalizado. Sobre isso, Sánchez (2002, p. 84):

O direito penal da globalização não é, sem embargo, todo o Direito Penal. Como aludido no início, concentra-se na delinquência econômica ou 
organizada e em modalidade delitivas conexas. Daí que se produza uma mudança significativa quanto ao modelo de delito que serve de referência a construçấo dogmática: em lugar do homicídio do autor individual, trata-se, por exemplo, de abordar atos de corrupção realizados por uma empresa que, por sua vez, comete delitos econômicos. A partir de tal constatação, depara-se com duas importantes alternativas: ou se acomete uma setorização das regras da Parte Geral do Direito Penal, ou se assume que, devido à poderosa força atrativa da nova criminalidade, também as modalidades clássicas de delinquência devam refletir a modificação das regras pelas quais vêm regidas. (Grifos do autor).

A proposta embora mais elaborada esbarra no cabedal garantista ao priorizar a setorização das regras. É necessário analisar a relação custo-benefício a fim de se avaliar a vantagem de qualquer das alternativas apresentadas pelo autor.

Em conclusão, é possível afirmar que, para Hassemer (1994), a solução ao Direito Penal na sociedade do risco perpassa pela institucionalização de um novo ramo do sistema penal, o direito interventivo. Já Sánchez (2002) esclarece ser necessário implementar-se um direito administrativo-sancionador; que é teleologicamente distinto do Direito Penal clássico. Este visa proteger bens concretos, volta-se contra a periculosidade concreta, respeitando, para tanto, todos os princípios penais clássicos. Quanto ao direito administrativo-sancionador, o autor esclarece que:

[...] o Direito Administrativo sancionador é o reforço da ordinária gestão da administração. Assim, também cabe afirmar que é o Direito sancionador de condutas perturbadoras de modelos setoriais de gestáo. Seu interesse reside na globalização do modelo, no setor em sua integridade, e por isso tipifica infraçôes e sanciona sob perspectivas gerais. Não se trata aqui do risco concreto, como risco em si mesmo relevante e imputável pessoalmente a um sujeito determinado, senão que o determinante é a visão macroeconômica ou macrossocial (as 'grandes cifras'; o 'problema estrutural' ou 'sistêmico'). (SANCHEZ, 2002, p. 116-117).

Tal postura implicaria inevitavelmente em clara mitigação do Direito Penal, que cederia parte de sua área de atuação em prol do sistema administrativo. Malgrado a inicial impressão de plausibilidade, alguns pontos permanecem sem solução, dentre eles, a fragilidade da seara administrativa no tocante a efetiva cobertura protetiva do bem jurídico razão que, em sentido oposto, deflagrou o processo de expansão do direito penal. Ademais, tal providência demandaria que os Estados fossem dotados de órgãos administrativos competentes fortalecidos e imparciais, além de tecnicamente preparados para a boa aplicação das regras relacionadas à punição de tais infrações.

Em sentido diferente posiciona-se Baratta (2002), que tem criticado a função simbólica do direito penal, segue defendendo a bandeira de um direito penal mínimo, 
observando, contudo, que a expansão punitiva, em determinados tópicos, em contraponto a um necessário processo de despenalização em outros, consistiriam em providências de grande valia na estratégia de otimização do sistema penal pós-moderno.

Tal proceder implicaria em "um reforço penal em áreas de interesse social para a vida dos indivíduos e da comunidade: a saúde, a segurança do trabalho, a integridade ecológica etc." e arremata, sugerindo, em seguida: "Trata-se de dirigir os mecanismos da reação institucional para o confronto da criminalidade econômica, dos grandes desvios criminais dos órgãos do corpo do Estado, da criminalidade organizada [...]" (BARATTA, 2002, p. 202).

Significativa a percepção que expóe Baratta (2002, p. 203) quando faz ponderaçóes de ordem processual, explicando o diferencial inerente ao novo direito penal encampado pela sociedade do risco, assim dispóe o autor: "trata-se ao mesmo tempo, de assegurar uma maior representação processual em favor dos interesses coletivos.” Merece guarida a perspectiva de uma "maior representação processual", em se tratando de interesses coletivos.

Por este norte, em sede de tratamento conferido aos delitos ambientais, não se vislumbra a solução na perigosa flexibilização decantada pelas propostas anteriores; antes se almeja uma mais acurada representação processual dos interesses coletivos, como expressão legitimante do sistema penal.

Sendo o processo, pelo procedimento que lhe informa, irrefutável instrumento de garantias no sistema jurídico, principalmente no sistema jurídico-penal, evidencia-se o equilíbrio da proposta teórica apresentada pelo citado autor, vez que contempla ambas as partes envolvidas na questão fática: o bem jurídico a ser protegido pela norma, segundo os novos ditames da sociedade do risco, representado pelo sujeito passivo, com expressiva atividade processual, e, por outro lado, o suposto autor do fato definido como crime, que terá em seu favor o processo como instrumento garantista.

\section{Posicionamentos e Perspectivas do Sistema Penal Ambiental: Uma Ne- cessária Abertura Democrática}

Em verdade do sistema penal, como subsistema social que é, pode advir a correta equação ao problema sócio-jurídico enfrentado pelo Direito Penal na sociedade do risco. Nesse aspecto, é indiscutível a relevância da inter-relação entre um sistema social e os indivíduos dentro de uma estrutura; traz-se a lume a observaçáo de Giddens (1989, p. 20):

Dizer que estrutura é uma 'ordem virtual' de relaçóes transformadoras significa que os sistemas sociais, como práticas sociais reproduzidas, não têm 'estruturas', mas antes exibem 'propriedades estruturais', e que a 
estrutura só existe, como presença espaço-temporal, em suas exemplificaçôes em tais práticas e como traços mnêmicos orientadores a conduta de agentes humanos dotados de capacidades cognoscitivas.

Para melhor examinar tal hipótese, necessário observá-la sob uma perspectiva ampla à luz da construção teórica de sistema cunhada por Luhmann (1995). Inicialmente, destaca-se a existência do sistema social funcionalmente diferenciado, devendo o sistema legal ser compreendido como um de seus subsistemas e que o sistema penal, por sua vez, é um subsistema do legal. Ressalte-se, contudo, a autonomia imanente de cada sistema. Nesse sentido:

Tal sistema constitui a si próprio, a partir de suas funçóes, determinadas no nível do sistema societário. Os arranjos função/sistema requerem total autonomia funcional porque nenhum outro sistema desempenhará as mesmas funçôes que aquele. Nesse sentido, a autonomia não é um objetivo perseguido pelo sistema, mas uma necessidade fática. (LUHMANN, 1995, p. 112).

Observe-se que em se tratando de sistema legal ou, para ser mais específico, sistema penal, a teoria de Luhmann (1995) conduz ao entendimento de que as unidades elementares que o compóem e o próprio sistema considerado em si mesmo serão ativados, perfazendo o que o autor denomina de redução de complexidades, que, uma vez realizada, permitirá ao sistema penal subordinar os estímulos recebidos do ambiente sociojurídico onde está inserido, ao seu próprio esquadro de funcionamento.

Para tal compreensão, Luhmann (1995) abeberou-se na biologia, onde, a partir do conceito de autopoiese desenvolvido por Maturana e Varela (1980), na década de setenta, obteve um significativo giro epistemológico, propiciando, também na área das ciências sociais, uma eficiente observação do meio e de suas características, a partir de uma perspectiva autopoiética.

Sendo assim, no âmbito do sistema penal ambiental, cumpre, à luz do marco teórico autopoiético, examinar a dinâmica desse sistema ou subsistema - se considerado como parte de um sistema jurídico e de um sistema social. Indaga-se, pois, poderia esse sistema, fechado em si mesmo, deixar-se confundir com o ambiente a partir da insistência e intensidade das irritaçóes ou estímulos recebidos? O próprio Luhmann (1997, p.44) cuida de esclarecer esse ponto, afirmando que: "[...] O sistema nunca chegaria a construir sua própria complexidade e o seu próprio saber se fosse confundido com o ambiente".

Não obstante Luhmann (1997) considere o sistema legal, um sistema fechado, isso não significa a ausência absoluta de interação ou conexóes com o ambiente onde está instalado. Portanto, não se olvide da sua integração com o ambiente a partir de estímulos externos, que serão tratados e concebidos - ou náo - pelo sistema, tudo conforme o seu 
perfil de atividade. Nesse sentido, Luhmann (1997, p. 44) esclarece, em outras palavras, que ser aberto fundamenta-se em ser fechado, porque só é possível conhecer o que é diferente e assevera: "Porque o sistema nunca chegaria a construir sua própria complexidade e o seu próprio saber se fosse confundido com o ambiente".

Por fim, feita esta breve digressão teórica, é necessário afirmar que tais constataçôes conduzem à conclusão de que o sistema penal só poderá adequadamente controlar a criminalidade própria da sociedade do risco, especialmente a criminalidade ambiental, se conseguir se manter verdadeiramente como sistema, isto é, se conseguir se manter em patamar teórico distinto daquele fomentado e vivenciado no ambiente social pós-moderno.

O fato é que os elementos do sistema penal ambiental são específicos desse sistema e devem ser respeitados como tal. Assim, a criminalidade ou delinquência ambiental apresenta as suas peculiaridades, que se não forem devidamente consideradas implicará na ausência de efetividade da proteção jurídica do objeto jurídico e, por consequência, na falibilidade do sistema jurídico - provocando o descrédito social da justiça penal.

Corroborando com a ideia de uma clara especificidade acerca do sistema penal ambiental, dispóe Ghersi (2001, p. 131) sobre a criminalidade ecológica:

Si para caracterizar la delincuencia ambiental tomamos como base la definición de Sutherland, que considera delitos de cuello blanco a los cometidos por uma persona respetable y de status social alto el curso de su ocupación, podemos incluir al delito ecológico e delito contra el medio ambiente dentro de este tipo de delitos ${ }^{1}$.

Em peculiar demonstração da especificidade desse tipo de delito, de acordo com Beloff (1994, p. 156), seria possível denominá-los de “delitos de cuello verde”. É precisamente nesse ponto que reside um aporte significativo da especificidade do direito penal ambiental que, embora provocador de ofensas jurídicas de grande envergadura, acaba por propiciar a inércia ou pouca efetividade dos aparatos ideológicos do Estado. Assim ocorre por interesse das classes dominantes o que teoricamente é discutido pela Criminologia, como explica Guerrero (2008, p. 54):

Desde el punto de vista criminológico, la delincuencia económica se define como las infraciones lesivas del orden económico cometidas por personas pertencientes a estratos altos em el ejercicio de su actividad profesional. La transcendencia social de esta delincuencia se manifiesta, em primer término, por la cuantía de los daños ocasionados y em segundo

1 "Se para caracterizar a delinqüência ambiental tomamos como base a definição de Sutherland, que considera delitos de colarinho branco aos cometidos por uma pessoa respeitável e de status social alto o curso de sua ocupação, podemos incluir ao delito ecológico e delito contra o meio ambiente dentro deste tipo de delitos". (Tradução nossa) 
lugar, por el reclutamiento del autor entre los miembros de la alta sociedad. Em muchas ocasiones, por el poder político o económico que ejerce, el delincuente de cuello blanco, logra que terceros o subalternos sean los autores materiales del hecho delictivo, lo que dificulta, sin duda alguna, la persecución del autor que realmente há dominado la acción, Estos son los rasgos criminológicos de mayor trascendencia. También debe destacarse, aunque en um segundo plano, que em este tipo de infracciones se lesiona, em muchas ocasiones, la confianza, explícita o implícita, em la economía ${ }^{2}$.

A par disso, e mais aprofundadamente, reflete-se sobre a questão da justiça penal como instrumento diferencial de controle das ilegalidades:

Não há uma justiça penal destinada a punir todas as práticas ilegais e que, para isso, utilizasse a polícia como auxiliar, e a prisão como instrumento punitivo, podendo deixar no rastro de sua açáo o resíduo inassimilável da "delinquência". Deve-se ver nessa justiça um instrumento para o controle diferencial das ilegalidades. Em relação a este, a justiça criminal desempenha o papel de caução legal e princípio de transmissão. Ela é um ponto de troca numa economia geral das ilegalidades, cujas outras peças são (não abaixo dela, mas a seu lado) a polícia, a prisão e a delinquência (FOUCAULT, 1987, p. 309).

E o autor continua sua reflexão acerca dos mecanismos punitivos e as inconsistências cotidianas a singrar as instâncias do poder estatal, onde, quase sempre, o que se obtém é espaço para justificação da ilegalidade da classe dominante. Eis um grande problema social.

A invasão da justiça pela polícia, a força de inércia que a instituição carcerária opóe à justiça, não é coisa nova, nem efeito de uma esclerose ou de um progressivo deslocamento do poder; é um traço de estrutura que marca os mecanismos punitivos nas sociedades modernas. Podem falar os magistrados; a justiça penal com todo o seu aparelho de espetáculo é feita para atender à demanda cotidiana de um aparelho de controle meio mergulhado na sombra que visa engrenar uma sobre a outra polícia e

2 "Desde o ponto de vista criminológico, a delinquencia econômica define-se como as infraçôes lesivas da ordem econômica cometidas por pessoas pertencentes a estratos altos no exercício de sua atividade profissional. A transcendência social desta delinquencia manifesta-se, em primeiro termo, pela quantia dos danos ocasionados e em segundo lugar, pelo recrutamento do autor entre os membros da alta sociedade. Em muitas ocasiōes, pelo poder político ou econômico que exerce, o delinqüente de colarinho branco, consegue que terceiros ou subalternos sejam os autores materiais do fato delitivo, o que dificulta, sem dúvida alguma, a perseguição do autor que realmente há dominado a açấo. Estes são os rasgos criminológicos de maior transcendência. Também deve se destacar, ainda que num segundo plano, que neste tipo de infraçôes se lesiona, em muitas ocasióes, a confiança, explícita ou implícita, na economia”. (Tradução nossa) 
delinquência. Os juízes são os empregados, que quase não se rebelam, desse mecanismo. Ajudam na medida de suas possibilidades a constituição da delinquência, ou seja, a diferenciação das ilegalidades, o controle, a colonização e a utilização de algumas delas pela ilegalidade da classe dominante (FOUCAULT, 1987, p. 309).

Sem embargo, Gomes e García-Pablos de Molina (2000, p. 66) assinalam que:

Para a Criminologia o delito se apresenta, antes de tudo, como 'problema' social e comunitário, que exige do investigador uma determinada atitude (empatia) para se aproximar dele. [...] um determinado fato ou fenômeno deve ser definido como problema social somente se concorrem as seguintes circunstâncias: que tenha uma incidência massiva na população; que referida incidência seja dolosa, aflitiva; persistência espaço-temporal; falta de um inequívoco consenso a respeito de sua etiologia e eficazes técnicas de intervenção no mesmo e consciência social generalizada a respeito de sua negatividade (Grifos dos autores).

Em verdade, se os crimes em geral apresentam-se com as características de problema social e comunitário, muito mais se observa tais traços nos crimes ambientais. Como se observa, o delinquente ambiental, espécie do gênero delinquente do colarinho branco, é distinto do criminoso comum, por isso requer uma estratégia processual igualmente diferenciada, sob pena de faltar efetividade à tutela penal ambiental. Em breve relance sobre essa questão, novamente traz-se à colação Guerrero (2008, p. 56), quanto aos efeitos materiais e processuais dessa espécie de criminalidade:

Existía um sentimiento relativamente desorganizado del público hacia esta clase de delitos, sus efectos son difusos y los medios masivos no expresan sentimientos morales organizados. Em la actualidad, la situación se há tornado diferente, pero no cambió em su esencia: la 'corrupción' es el término designado para denominar a los delitos generales de 'cuello blanco'. Sin enbargo, los casos de corrupción que por general son denunciados desde la prensa, em la gran mayoria de los casos, se termina en un punto cero donde nada se puede probar, en tanto que se denuncia uma complicidad entre el poder politico y el poder judicial (Grifos nossos). ${ }^{3}$

É pertinente o destaque acerca da dificuldade probatória nessa espécie de criminalidade. Por outro lado, observa-se a existência de uma cumplicidade entre os poderes, o

3 "Existia um sentimento relativamente desorganizado do público para esta classe de delitos, seus efeitos são difusos e os meios em massa não expressam sentimentos morais organizados. Na atualidade, a situação se há tornado diferente, mas não mudou em sua essência: a 'corrupção' é o termo designado para denominar aos delitos gerais de "colarinho branco". No entanto, os casos de corrupção que em geral são denunciados desde a imprensa, na grande maioria dos casos, terminam-se num ponto zero onde nada se pode provar, enquanto se denuncia uma cumplicidade entre o poder politico e o poder judicial". (Tradução nossa) 
que, por si só, já é suficiente para conduzir a conclusão de que o sistema penal ambiental reclama, em verdade, um elemento diferenciador para funcionar adequadamente.

Por outro prisma, indica também Ghersi (2001, p. 135), o entrave da questão probatória quanto a este tipo de criminalidade: "A concepción, en la cual la vida y la salud de la población son el objeto último de protección, aparece el inconveniente de la difícil prueba de la relación de causalidad del hecho contaminante con el perjuicio ocorrido" ${ }^{4}$.

Para além de todas as discussóes de ordem filosóficas ventiladas acerca da criminalidade ambiental, pragmaticamente observa-se que a questão probatória é talvez a mais tormentosa que se apresenta. Desse modo, reconhecendo como complexas as questóes penais ambientais, por tudo que já foi demonstrado, urge esquematizar o processo penal ambiental de elemento especializante, dotado de saberes e poderes que o legitimem a otimizar o procedimento, particularmente no aspecto probatório. Em sentido assemelhado, pensou Franza (2007, p. 131):

La complejidad y especificidad de este tipo de delitos hace que cada vez apareza más necesaria la creación de una Fiscalía Especial de Medio Ambiente em cada Tribunal Superior de Justicia y em cada Audiencia Provincial, dotada de suficientes fiscales y adecuados medios (por ejemplo: ecotoxicólogos forenses). Esta figura de la Fiscalía Especial ya existe, adstrita a la Fisclía General del Estado, para los delitos relativos a la corrupción económica o al narcotráfico ${ }^{5}$.

Insta esclarecer que tal sujeito processual viria fortalecer a proposta de um sistema penal adequado aos desafios que as especificidades inerentes à criminalidade ambiental impóem, sem ter que abrir mão da tutela penal em prol de uma tutela exclusivamente administrativa ou, sem que seja necessário partir em uma verdadeira cruzada criminal, no dorso de um direito penal do inimigo, sem, contudo, lograr uma proteção mais efetiva do bem jurídico que a lei visa proteger.

Nesse sentido, é preocupante a tendência pós-moderna de administrativização do direito penal, uma vez que tal técnica insere-se no sistema administrativo ou, pior ainda, sobrepóe este sistema ao sistema penal, em confusa operação hermenêutica. Sobre os vícios próprios da seara administrativa, dispóe Habermas (1997, p. 109):

4 "A concepção, na qual a vida e a saúde da população são o objeto último de proteção, aparece o inconveniente da difícil prova da relaçấo de causalidade do fato contaminante com o prejuízo ocorrido". (Tradução nossa)

5 "A complexidade e especificidade destes tipo de delitos fazem que cada vez apareça mais necessária a criação de uma Promotoria Especial de Meio ambiente em cada Tribunal Superior de Justiça e em cada Audiência Provincial, dotada de suficientes promotores e adequados meios (por exemplo: ecotoxicólogos forenses). Esta figura da Promotoria Especial já existe, adstrita à Fiscalía General do Estado, para os delitos relativos à corrupção econômica ou ao narcotráfico". (Tradução nossa) 
Os sistemas da economia e da administração têm a tendência de fecharse contra seus mundos circundantes e de obedecer unicamente aos próprios imperativos do dinheiro e do poder administrativo. Eles rompem o modelo de uma comunidade de direito que se determina a si própria, passando pela prática dos cidadãos.

Por isso, para garantir a validade e a certeza, racional e legal, das decisóes acerca da proteção jurídica ambiental é que se orienta a via do direito penal, contudo, será necessária a adequada fundamentação numa teoria do discurso. Afinal, sabe-se que a conduta livre de cada cidadão será sempre orientada por suas perspectivas valorativas, sendo esta a face da medalha. O reverso desta mesma medalha, contudo, é representado pela necessária mitigação aos interesses dos indivíduos e dos grupos felizmente exercida pelo controle coercitivo do direito.

Nesse passo, convém trazer a lume os ideais da teoria do agir comunicativo, apresentada por Habermas (1997), onde em última análise, tem-se que o que legitima verdadeiramente as normas são os processos democráticos, por todos os seus meios de realização, inclusive, a atuação cidadã quotidiana através do exercício da capacidade, individual e coletiva, de escolhas, de construção argumentativa em defesa de interesses próprios. Os princípios do discurso somente podem ser semeados e colhidos nos férteis solos da democracia.

Tal princípio, aplicado na seara jurídica, confirma a autonomia e a liberdade da participação cidadã em todos os processos sociais, especialmente os judiciais. Ressalta, por consequência, valores normativos considerados e garantidos, tais como: o direito à liberdade de expressar-se, associar-se, direito inclusive de garantir o exercício dos demais direitos perante a qualquer dos Poderes constituídos.

Em verdade, a lei, ou melhor, sua adequada aplicação, deve garantir, sem fazer assepsia de qualquer ordem no âmbito do sistema penal, aí incluído o sistema penal ambiental, com toda a sua carga de especificidade, o exercício democrático pleno, tal como enfatiza Habermas (1997, p. 164) ao afirmar a importância "de uma juridificação simétrica da liberdade comunicativa de todos os membros do direito; e esta exige, por seu turno, uma formação discursiva da opinião e da vontade que possibilita um exercício da autonomia política através da assunção dos direitos dos cidadãos".

O direito é fundamentalmente importante para que o exercício do princípio do discurso seja princípio basilar da democracia, pois abre espaço à participação de todos. Para tanto, a autonomia política necessita da democracia, fonte de onde emanam todas as formas de concretização dos discursos. Sobre uma nova proposta democrática, dispóe Santos (2006, p. 276):

A nova teoria de democracia - que também poderíamos designar por teoria democrática pós-moderna para significar a sua ruptura com a 
teoria democrática liberal - tem, pois, por objectivo alargar e aprofundar o campo político em todos os espaços estruturais da interação social. No processo, o próprio espaço político liberal, o espaço da cidadania, sofre uma transformação profunda. A diferenciação das lutas democráticas pressupôe a imaginação social de novos exercícios de democracia e de novos critérios democráticos para avaliar as diferentes formas de participação política.

E continua Santos (2006, p. 276), desta feita acerca de cidadania:

$\mathrm{E}$ as transformaçôes prolongam-se no conceito de cidadania, no sentido de eliminar os novos mecanismos de exclusão da cidadania, de combinar formas individuais com formas colectivas de cidadania e, finalmente, no sentido de ampliar esse conceito para além do princípio da reciprocidade e simetria entre direitos e deveres.

Resta, pois, patente a necessidade de fortalecer a democracia e a cidadania no sentido mais abrangente dos termos. Por isso, o anúncio de todo e qualquer instrumento que possa fomentar um sistema penal ambiental democrático e cidadão, deverá ser bem compreendido e acolhido para que possa frutificar abundantemente.

\section{Processo Penal Ambiental e Direitos Fundamentais: Um Necessário Con- traponto ao Binômio Saber-Poder}

No magistério de Ferrajoli (2006), em sua obra Direito e razão: teoria do garantismo penal, o problema da verdade processual repousa no binômio saber-poder, que deve ser observado, cuidadosamente, de modo a não prestar-se a transmudar a ideia de justiça em injustiça patente. Pondera o autor que "se uma justiça penal integralmente 'com verdade' constitui uma utopia, uma justiça penal completamente 'sem verdade' equivale a um sistema de arbitrariedade" (FERRAJOLI, 2006, p. 48).

Em busca dessa verdade, apresenta o autor o o sistema garantista, comportando importantes axiomas para exercício do jus puniendi estatal, contudo, para ilustrar o presente trabalho insta destacar o terceiro, o quinto e o sexto princípios. No que diz respeito à separação das atividades processuais, supóe-se que um processo só representará os interesses de um Estado Democrático, do qual é instrumento, quando, necessariamente, conseguir se instaurar de modo a obedecer à efetiva separação entre as atividades de acusação, defesa e julgamento; a cada uma dessas cabe desenvolver a missáo que lhe diz respeito.

O que se obtém de verdade a partir da produção das partes contrapostas (acusação e defesa) será o material destinado ao julgador para análise e subsídio de suas decisóes e quanto mais material probatório sedimentar a análise, por consequência, a fundamentação do julgador, mais aproximada da verdadeira justiça estará a decisão proferida e o processo atingirá o seu real objetivo. 
É precisamente nesse ponto que se demonstra válida a proposta de inserção direta do cidadão, comprometido com as questôes ambientais, como amigo da corte, no bojo desse tipo de processo penal, vez que facilitaria a arregimentação probatória, além de viabilizar os necessários esclarecimentos técnicos, apoiando, sobremaneira, a atuação do julgador. Tal proposta se daria em sede de processo penal ambiental, especialmente pelo fato de se implicarem as questóes ambientais em aspectos probatórios, em regra, bastante complexos, o que acaba por dificultar o adequado e justo julgamento das questôes.

Assim, o sistema garantista que guarda íntima relaçáo com os preceitos de um Estado Democrático de Direito recepciona validamente todo e qualquer incremento processual que viabilize um processo mais justo. Neste esteio, o direito penal mínimo apresenta-se como uma importante técnica de efetiva proteção dos direitos fundamentais, representando a tutela da parte frágil em relaçáo à parte mais forte. Assim, tem-se que a parte frágil pode ser representada tanto pela vítima diluída pelos efeitos pulverizados do delito (vitimização difusa) como pelo réu, sob a mira da atuação estatal.

A tutela apresenta-se personificada no monopólio estatal da pena e materializada através do processo judicial, veículo ou instrumento para aplicação da pena justa, consequentemente, a estrutura processual deve, pois, ser pensada de tal modo que seja possível ao Estado, por meio desse instrumento, reduzir ao mínimo possível a margem de erro e o vácuo experimetado pelos julgamentos no Brasil, que tanto esbarram em fenômenos personificados em institutos que desqualificam a força democrática dos processos, tais como a insuficiência probatória e na prescrição.

Sob uma prespectiva garantista, há de se assegurar a justiça das decisôes, buscando evitar desvios, tanto para o mais (condenaçóes indevidas - sacrifício dos direitos individuais - o que pouco ocorre em casos de delitos ambientais), quanto para o menos (absolviçóes fundadas em incertezas plenamente dirimíveis, ou outra espécie de desfocada visão processual - sacrifício dos direitos difusos de obter adequada proteção ao meio ambiente equilibrado). Resta, pois, considerar que todas as estratégias que pretendam minorar o sacrifício desses bens jurídicos, especialmente aquelas que objetivam a legítima inserção do cidadão na dinâmica processual implicam em seguro constructo de justiça.

\section{Participação Cidadã no Processo Penal Ambiental}

A questâo ambiental está cada vez mais presente nas pautas dos Estados que compõem as comunidades internacionais. Diversos são os pontos de vistas a partir dos paradigmas defendidos e vivenciados por cada um desses Estados. Contudo, já não é possível pensar em diretrizes eminentemente liberais, como outrora se fazia, sem maiores preocupaçôes. Bem ou mal, a perspectiva ecológica, ao menos teoricamente, integra as preocupaçôes políticas dos diversos continentes. 
No plano jurídico, porém, ainda não é perceptível uma sensibilização ambiental na postura dos juristas. Ainda vigora uma perspectiva eminentemente vinculada ao paradigma antropocêntrico, vindo a questão ecológica apenas indiretamente, como mero complemento às obrigaçóes estatais, como se fosse possível, na prática, compartimentar o bem-estar individual e social da questão meio ambiente equilibrado.

Assim, os vínculos entre o perfil democrático de um povo e a questão ecológica indicam que esse enfrentamento faz presumir uma verdadeira superação da democracia liberal, suplantando o patamar meramente representativo e incrementando o cenário constitucional com os elementos próprios de uma democracia participativa e direta.

Trata-se, pois, de uma forma exigente, quase utópica de Estado, porém, não impossível. Segundo Canotilho (2004), um Estado constitucional ecológico tem como pressuposto a concepção e o direito integrados ou integrativos do ambiente.

Desse modo, o propósito para que se promova o desenvolvimento sustentável deve integrar o rol dos princípios que embasam a estruturação do Estado e a forma de organização social. Por isso, enfaticamente, pode-se afirmar: para que haja um Estado de Direito, este deve ser, ao mesmo tempo, constitucional, social, democrático e, também, um Estado ambiental.

É impossível que se veja o Estado de Direito como uma obra pronta e acabada. Não; um Estado não se termina de fazer; um Estado caminha e se refaz todos os dias nos sonhos e nas realizaçóes dos cidadãos - no sentido mais abrangente do termo. Trata-se de um processo interminavelmente dinâmico.

Sabe-se que, sob o manto de um Estado liberal, mas, visando atender aos anseios sociais, o Estado de Direito implementou o propósito de um Estado social, para tanto, incluiu diversos temas em seus conceitos-chave, tais como: a globalização e desenvolvimento tecnológico e científico, além do rol de direitos de terceira e quarta dimensóes - meio ambiente equilibrado; paz; informação; patrimônio comum da humanidade.

Por óbvio, nada disso se fará tão somente sob a responsabilidade exclusiva das forças estatais. Para que tal mudança possa ir adiante, em conformidade com as previsóes constitucionais de cada Estado soberano, é necessário incluir o cidadão, que já não pode se contentar com a condição de mero espectador. Sem dúvidas, nesse cenário, vai além a sua função. É preciso sair do passivo conforto de espectador e assumir o papel que lhe foi dado, sob pena de o espetáculo da vida democrática estagnar completamente.

Sem embargo, sob uma expectativa ambientalista a atuação cidadã ganha contornos de imprescindibilidade. A proposta de um Estado ambiental não pode sequer ser pensada, senão com a presença cidadã a orientar-lhe o curso. Entrementes, não se pode levar tal propósito aos extremos condenáveis, mesmo em se tratando da defesa do ambiente 
ecologicamente equilibrado, os propósitos calcados na hipertrofia do Estado penal, serão sempre nocivos aos postulados estatais democráticos em seu conjunto e, por isso, devem ser rechaçados.

Em verdade, equilíbrio e democracia ambiental caminham juntos no processo de uma interpretação pluralista da Constituição. Aliás, observa-se que nesse desiderato é que o intérprete da Constituição se revela plenamente; e ele não se resume aos representantes dos Poderes constituídos, não se restringe às autoridades: ele vai ao cidadáo que vivencia a norma constitucional em seus afazeres cotidianos. Nesse sentido, ilustrativo o seguinte entendimento acerca do que seja democracia:

A ideia fundamental da democracia é a seguinte: determinação normativa do tipo de convívio de um povo pelo mesmo povo. Já que não se pode ter o autogoverno, na prática quase inexequível, pretende-se ter ao menos a autocodificação das prescrições vigentes com base na livre competição entre opinióes e interesses, com alternativas manuseáveis e possiblidades eficazes de sancionamento político (MÜLLER, 2000, p. 57).

Para tal propositura, o cidadão tem que se demonstrar capaz de exercer uma cidadania ativa; consciente de que sua atuação é imprescindível para a conformação dos direitos e garantias fundamentais, cuja realização se verifica em sua rotina diária de interpretar e vivenciar a norma. Se necessário, poderá inserir-se validamente nas esferas de poder, investido por instrumentos legítimos, que o autorize a representação direta de seus interesses.

Sobre os participantes do processo de interpretação constitucional, afirma Häberle (1997, p. 19):

A intervenção sobre os que participam do processo de interpretação é, de uma perspectiva sócio-constitucional, consequência do conceito 'republicano’ de interpretação aberta que há de ser considerada como objetivo da interpretação constitucional.

Em verdade, para Häberle (1997), está aberto o círculo de intérpretes da Constituição, isto é, aquele circuito formado pelas autoridades cuja labuta cotidiana consiste na leitura, interpretação e aplicação da Constituição, assim considerados os juízes, membros do Ministério Público, advogados públicos e particulares e os operadores do direito de uma forma geral. Todos esses deverão coabitar no patamar interpretativo com os leigos. Na sua visão, "a sociedade é livre e aberta na medida em que se amplia o círculo dos intérpretes da Constituição em sentido lato” (HÄBERLE, 1997, p. 40).

Aspecto interessante é o que diz respeito à dimensão e intensidade do controle judicial dessas participaçóes cidadãs:

Ademais, a Corte Constitucional deve controlar a participação leal ( faire Beteiligung) dos diferentes grupos na interpretaçáo da Constituição, 
de forma que, na sua decisão, se levem em conta, interpretativamente, os interesses daqueles que não participam do processo (interesses não representados ou não representáveis). Considerem-se algumas questôes como aquelas relacionadas com a defesa do consumidor ou a defesa do meio-ambiente. Aqui se manifestam os 'interesses públicos' (HÄBERLE, 1997, p. 46).

Significativa a postura que atenta à necessidade de se levar em conta os interesses daqueles que não participaram do processo, mas que possuem interesses não representados. Nesse sentido, arremata o autor mencionando as consequências da utilização do direito processual constitucional:

Para a conformação e a aplicação do direito processual resultam consequências especiais. Os instrumentos de informaçáo dos juízes constitucionais - não apesar, mas em razão da própria vinculação à lei - devem ser ampliados e aperfeiçoados, especialmente no que se refere às formas gradativas de participaçáo e à própria possibilidade de participaçáo no processo constitucional (especialmente nas audiências e nas 'intervençóes') (HÄBERLE, 1997, p. 46).

Importante observação consiste no destaque da necessidade de ampliação e aperfeiçoamento dos instrumentos de informação dos juízes constitucionais. Abre-se aqui um parêntese para estender a mesma observação aos juízes e tribunais em geral, considerando que o sistema jurídico é fechado e atua que em autopoiese, conclui-se que não causa qualquer entrave essa proposta de extensão, desde que se descutam questóes de ordem constitucional; haveria uma glosa com adoção do critério de competência material, o que confirmaria a atuação do direito processual constitucional fortalecendo a participação democrática, como sugere Härbele (1997, p.48):

Devem ser desenvolvidas novas formas de participação das potências públicas pluralistas enquanto intérpretes em sentido amplo da Constituição. $\mathrm{O}$ direito processual constitucional torna-se parte do direito de participação democrática. A interpretação constitucional realizada pelos juízes pode-se tornar, correspondentemente, mais elástica e ampliada sem que se deva ou possa chegar a uma identidade de posiçóes com a interpretação do legislador.

Por fim, observa-se que à luz da hermenêutica constitucional proposta por Häberle (1997), adequada à sociedade pluralista ou, como afirmara o autor, à sociedade aberta dos intérpretes da Constituição, denota-se prontamente possível a participação cidadã direta, isto é, sem intermediários, no labor interpretativo do texto constitucional. Além disso, o direito processual constitucional (incluindo o direito processual constitucional de caráter penal ambiental) incorpora a pauta de participação democrática no processo 
como assinala Häberle (1997), sem precisar, para tanto, recorrer ao Poder Legislativo no sentido de autorizar, por lei expressa, tal prática.

Em verdade, somente viabilizando juridicamente a inserção do cidadão, representando a vitimização difusa, própria da seara penal ambiental, no contexto desse tipo específico de processo penal, mediante a presença do cidadão reconhecidamente comprometido com a causa ambiental, junto aos juízos singulares e aos tribunais, na condiçáo processual de amigo da corte, com todas as limitaçóes e prerrogativas próprias desse sujeito processual, é que se democratizará o processo, fomentando uma postura de tutela preventiva e efetiva do meio ambiente. Mas a quem atribuir essa figura, a princípio estranha ao processo penal?

A título de exemplo, apontam-se: os participantes das ONG's pertinentes à causa do ambiente; os professores, estudantes e pesquisadores com experiência na temática em sua rotina de atuação; os profissionais e pareceristas com formação nas áreas diretamente relacionadas à questáo da proteção ambiental, entre outros que possam justificar o seu interesse e legitimidade participativa na causa, segundo o arbítrio do julgador responsável pela análise da inserção solicitada.

Com isso, é imperativo lógico uma modernização ou refinamento do processo constitucional de tal forma que seja possível estabelecer uma comunicação plena entre todos os participantes desse processo interpretativo; afinal, como já afirmou Häberle (1997), não existe norma jurídica, senão norma jurídica interpretada. A interpretação, pois, é a luz que abre as portas da justiça a todos - às autoridades e, especialmente, aos cidadãos.

Construída a ideia de um processo penal ambiental mais efetivo, porém garantista, compreende-se que é impossível apreender a realidade em toda a sua complexidade, compartimentando-a. O conhecimento não é estanque e exige que as análises das questões científicas, máxime as questóes penais ambientais, sejam feitas sob uma perspectiva sistêmica.

\section{Conclusões}

Com a intenção de perscrutar quanto à efetividade do sistema processual penal tradicional, em sede de persecução penal das questóes ambientais, a pesquisa sustentou como questão teórica de base, a análise do sistema penal; visou investigar a possibilidade jurídica da participação direta do cidadão na dinâmica do sistema processual penal ambiental, mediante a inserção de um instrumento otimizador da efetividade daquele sistema.

Tal compreensão conduziu, a partir daí, ao exame da necessária comunicação entre os sistemas, que se entrelaçam e interagem mutuamente, em um ritmo variável, mas em movimento permanente. Nesse passo, avançaram-se os estudos para análise do sistema 
penal ambiental, compreendido no âmbito do sistema jurídico que, à luz de um agir comunicativo, observou o sistema jurídico, náo mais como um sistema fechado, mas um sistema necessariamente aberto, apto a comunicar-se com o sistema constitucional e este, com o sistema social e democrático do Estado de Direito em que está legitimaente inserido.

Este cotejo se deu sob o manto da análise dos postulados da sociedade do risco e da modernidade reflexiva; constatou-se, então, a parca efetividade do sistema penal tradicional, por incompatibilidades de ordem ideológica e pragmática, com os desafios impostos pelo novo cenário penal-ambiental, a interagir necessariamente com o sistema jurídico costitucional.

Precisamente nesse ponto identificou-se que, sob o argumento de conferir efetividade à tutela ambiental (entre outras tutelas penais difusas) por esse sistema, promoveu-se um incremento quantitativo e qualitativo das normas penais, destacando-se, a postura de administrativização da tutela penal; tudo em clara adesão aos postulados do direito penal máximo, visando conferir efetividade a esse sistema.

Por óbvio, tal análise sócio-jurídica verificou- se como proposta sedimentada no funcionalismo penal; contudo, considerando as premissas do Estado Democrático de Direito, optou-se por seguir a linha de investigação rumando ao funcionalismo sistêmico moderado, cujos propósitos se harmonizam com os valores e princípios próprios desse tipo de Estado.

A partir dessa constatação, a pesquisa seguiu pela via oposta àquela percebida como padrão pelos defensores de um Estado penal, em detrimento ao Estado social. Assim, com suporte teórico nos postulados do minimalismo e do garantismo penal, promoveu-se um contraponto ao paradigma de proteção ao ambiente atrelado ao perfil dogmático de um direito penal expansionista.

Ao final dessa análise, restou perceptível que não era a ausência normativa, tampouco a modalidade das sançóes penais ambientais que fragilizavam esse sistema jurídico. Compreendeu-se, então, que a pouca efetividade da persecução penal ambiental, despontava precisamente da natureza peculiar do objeto jurídico que pretendia proteger e, ainda mais intensamente, da relação de reciprocidade (por força da base cultural que os aproxima), que tal objeto despertava entre os sujeitos que compóem o clássico processo penal, aplicado pelo sistema, indistintamente a todas as questóes penais, inclusive, à questão penal ambiental.

Com efeito, advém da cultura o grau de importância conferido, ou não, a um objeto jurídico que lei penal visa proteger. Não obstante constituir-se o meio ambiente equilibrado em uma das diretrizes contempladas no Estado democrático de direito brasileiro, é a questão cultural que confere a tônica do tratamento normativo que lhe é conferido; qualquer que seja o ordenamento jurídico de análise. 
É pontualmente dessa constataçấo que surge a necessidade de abertura do sistema, tanto no aspecto material - acima referenciado, quanto no aspecto processual - sobre esse ponto é que repousa a proposta inovadora de solução à problemática apresentada: a inserção do cidadão no processo penal ambiental, na figura do amigo da corte.

Por óbvio se exigiu um embasamento teórico contundente para justificar esse postulado. Dentre as diversas variáveis investigadas, uma base justificante é comum, ou seja, a possibilidade jurídica de se realizar uma interpretação aberta da Constituição e, a partir desse ponto, iluminar todo o sistema jurídico, inclusive o sistema processual penal, que ainda mais que qualquer outro sistema processual deve adesão plena aos propósitos constitucionais.

Assim, concluiu-se que se no Brasil, a título de recorte geográfico representativo de um Estado Democrático de Direito, é possível inserir a figura do amigo da corte na dinâmica do processo constitucional, que tramita no órgão de cúpula do Judiciário, muito mais simples será inserir tal sujeito no bojo do processo penal ambiental em istâncias e juízos primários. Nesse ponto, especialmente justificada a inserção por tratar-se de processo cujo objeto é de interesse difuso e prontamente resguardado por toda Constituição pertinente a um Estado Democrático de Direito.

Com efeito, nesse sistema processual de características muito especiais - processo penal ambiental - o juiz precisa julgar sistemicamente, mais que qualquer outra espécie de processo, o que torna o julgamento muito mais complexo. Nesse campo processual, o juiz julga crimes cuja vítima é toda a coletividade, inclusive o próprio julgador, e até mesmo o réu, é vítima de sua própria conduta criminógena; em verdade a presença do amigo da corte é processualmente indispensável para o embasamento ético do julgamento.

Convém explicar que se constatou nesta alteração inovadora na sistemática do processo penal ambiental, a possibilidade de uma tutela mais efetiva do meio ambiente, sem que para isso seja necessário flexibilizar os direitos e garantias individuais do réu, isto é, abdicar dos princípios vetores do garantismo penal. Observe-se que, por esse prisma, a construção sistemática que insere o amigo da corte no contexto do processo penal ambiental, conseguiu render homenagens (simultâneas) ao binômio: efetividade e segurança; ultrapassando, assim, a impressão doutrinária que afirma tratar-se de qualitativos processuais antagônicos.

Contudo, observou-se que a partir de uma interpretaçấo democrática e aberta do sistema jurídico processual, para tornar legítima e qualitativamente válida a inserção do amigo da corte como presença cidadá no processo penal ambiental, exige-se do cidadão legitimado uma postura eticamente responsável e que o mesmo seja engajado de algum modo à causa ambiental, independente da área de conhecimento a que se vincule, ou da atividade profissional que desenvolva rotineiramente. 
Assinalou-se que o conteúdo ético do discurso jurídico-penal, para se revelar válido e adequado aos embasamentos do Estado Democrático de Direito, deverá ser capaz de devolver ao sistema a sua racionalidade perdida, diminuindo o seu nível de violência e ampliando o seu perfil democrático e cidadão.

\section{Referências}

BARATTA, Alessandro. Criminologia critica e critica do direito penal: Introdução à sociologia do direito penal. Traduçáo de Juarez Cirino dos Santos. 3 ed. Rio de Janeiro: Renavan, 2002.

BELOFF, Mary. Lineamientos para una politica criminal. Buenos Aires: Puerto, 1994.

BOTTINI, Pierpaolo Cruz. Crimes de perigo abstrato e princípio da precaução na sociedade do risco. Sáo Paulo: Revista dos Tribunais, 2007.

FERREIRA, Hedine Sivini; LEITE, José Morato (org.). José Joaquim Gomes Canotilho. Estado de direito ambiental: tendências, aspectos constitucionais e diagnósticos. Rio de Janeiro: Forense Universitária, 2004.

FERRAJOLI, Luigi. Direito e razão: teoria do garantismo penal. Trad. Ana Paula Zomer Sica; Fauzi Hassan Choukr; Juarez Tavares; Luiz Flávio Gomes. 2. ed. rev. e ampl. São Paulo: Revista dos Tribunais, 2006.

FOUCAULT, Michel. Vigiar e punir: nascimento da prisão. Trad. Raquel Ramalhete. Petrópolis, Vozes, 1987.

FRANZA, Jorge Atilio. Delito Ambiental: aspectos penales, contraencionales y de faltas doctrina, legilación, jurisprudencia. Buenos Aires: Ediciones Juridicas, 2007.

GHERSI, Sebastián R. Derecho y reparación de daños: tendencia jurisprudencial anotada y sistematizada - daño al medio ambiente y al sistema ecológico. Responsabilidade civil, administrativa y penal. In: GHERSI, Carlos (Org.). La delincuencia ecológica. Buenos Aires: Editorial Universidad, 2001.

GIDDENS, Anthony. A constituição da sociedade. São Paulo: Martins Fontes, 1989.

GOMES, Luiz Flávio; GARCÍA-PABLOS DE MOLINA, Antônio. Criminologia. 3. ed. São Paulo: Editora Revista dos Tribunais, 2000.

GUERRERO, Ramiro Anzit. Criminolgía: evolución e análisis. Buenos Aires: Seguridad y defensa, 2008.

HÄBERLE, Peter. A sociedade aberta dos intérpretes da constituição: contribuição para a interpretação pluralista e "procedimental" da constituição. Trad. Gilmar Ferreira Mendes. Porto Alegre: Sergio A. Fabris, 1997. 
HABERMAS, Jürgen. Direito e democracia, entre facticidade e validade. Vol. I. Trad. Flávio Beno Siebeneichler. Rio de Janeiro: Tempo Brasileiro, 1997.

HASSEMER, Winfried. Três temas de direito penal. Porto Alegre: AMP/ Escola Superior do Ministério Público, 1994.

LUHMANN, Niklas. O conceito de sociedade. In: NEVES, C. B. ; SAMIOS, E. M. B. (Org.). Niklas Luhmann: a nova teoria dos sistemas. Porto Alegre: Ed. UFRGS, 1997.

MATURANA, Humberto; VARELA, Francisco J. Autopoiesis and cognition. Boston: Reidel, 1980.

MEZZAROBA, Orides; MONTEIRO, Cláudia Sevilha. Manual de metodologia da pesquisa no Direito. 2 ed. rev. São Paulo: Saraiva, 2005.

MÜLLER, Friedrich. Quem é o povo? A questão fundamental da democracia. Trad. Peter Naumann. São Paulo: Max Limonad, 2000.

ROXIN, Claus. Derecho penal: parte general. Madri: Civitas, 2004.

SÁNCHEZ, Jesus Maria Silva. A expansão do direito penal: aspectos da política criminal nas sociedades pós-industriais. São Paulo: Revista dos Tribunais, 2002.

SANTOS, Boaventura de Sousa. Pela mão de Alice: o social e o político na pós-modernidade. 11 ed. São Paulo: Cortez, 2006.

WACQUANT, Löic. As prisóes da miséria. Rio de Janeiro: Jorge Zahar, 2001. 